\title{
Modified single innominate artery cannulation with low flow cardiopulmonary bypass during repair of interrupted aortic arch
}

\author{
Q Chen ${ }^{1 *}$, M Caputo $^{1}$, S Stoica' ${ }^{1}$, G Stuart ${ }^{2}$, A Wolf $^{3}$, A Parry $^{1}$ \\ From 23rd World Congress of the World Society of Cardio-Thoracic Surgeons \\ Split, Croatia. 12-15 September 2013
}

\section{Background}

Conventional techniques for repairing interrupted aortic arch (IAA) using deep hypothermic circulatory arrest (DHCA) is known to be associated with the risk of postoperative neurological injury. We have used alternative technique with direct innominate artery cannulation for continuous cerebral perfusion, without DHCA, during repair of IAA in neonates regardless of patient's weight.

\section{Methods}

Between September 1999 and July 2011, 32 consecutive children with IAA (13 type A, 19 type B) underwent repair using continuous, hypothermic $\left(18{ }^{\circ} \mathrm{C}\right)$ low flow $\mathrm{CPB}$ without circulatory arrest. Associated cardiac lesions were Truncus Arteriosus (4), VSD (22), DORV (2), aortopulmonary window (4). Associated cardiac lesions were corrected in all except the DORV which were banded.

\section{Results}

Age at time of surgery was 7 days (4-120 days) and weight $3.1 \mathrm{~kg}$ ( 2.1 to $5.8 \mathrm{~kg}$ ). Selective cerebral perfusion was maintained in all patients throughout aortic reconstruction. During the period of selective cerebral perfusion, pump flow rate was maintained at $30 \mathrm{mls} / \mathrm{kg} / \mathrm{min}$. Aortic cross clamp time, low-flow, and total CPB time were 66 (42-114), 29 (18-41) and 109 (83-217) minutes, respectively. There were no deaths or neurological injury in this series. Postoperative ventilation time, and length of ICU and hospital stay were 3 (2-14), 5 (3-21), and 13 (6-27) days, respectively. Follow-up, complete at 48 months (21-156), revealed no late neurologic sequelae

\footnotetext{
* Correspondence: qiangchen79@hotmail.com

${ }^{1}$ Cardiac Surgery, Bristol Royal Hospital for Children, Bristol, UK

Full list of author information is available at the end of the article
}

nor innominate artery complications. There were three late re-stenosis of the aortic arch requiring balloon dilatation in 2 and surgical repair in 1.

\section{Conclusions}

Direct innominate arterial cannulation with continuous selective cerebral perfusion can be safely applied during repair of IAA even with low birth weight neonates. It is technical simple and associated with excellent clinical outcomes.

\section{Authors' details}

${ }^{1}$ Cardiac Surgery, Bristol Royal Hospital for Children, Bristol, UK. ${ }^{2}$ Cardiology, Bristol Royal Hospital for Children, Bristol, UK. ${ }^{3}$ Cardiac Anaesthesia, Bristol Royal Hospital for Children, Bristol, UK.

Published: 11 September 2013

doi:10.1186/1749-8090-8-S1-O240

Cite this article as: Chen et al: Modified single innominate artery cannulation with low flow cardiopulmonary bypass during repair of interrupted aortic arch. Journal of Cardiothoracic Surgery 2013 8(Suppl 1): O240.

Submit your next manuscript to BioMed Central and take full advantage of:

- Convenient online submission

- Thorough peer review

- No space constraints or color figure charges

- Immediate publication on acceptance

- Inclusion in PubMed, CAS, Scopus and Google Scholar

- Research which is freely available for redistribution 